Research, Society and Development, v. 10, n. 4, e22810414059, 2021

(CC BY 4.0) | ISSN 2525-3409 | DOI: http://dx.doi.org/10.33448/rsd-v10i4.14059

\title{
Acetylcholinesterase inhibitory potential and lack of toxicity of Psychotria
}

\section{carthagenensis infusions}

\author{
Potencial inibitório da acetilcolinesterase e ausência de toxicidadle de infusões de Psychotria \\ carthagenensis
}

Potencial inhibidor de la acetilcolinesterasa y falta de toxicidad de las infusiones de Psychotria carthagenensis

Received: 03/19/2021 | Reviewed: 03/24/2021 | Accept: 03/29/2021 | Published: 04/08/2021

Giovana Coutinho Zulin Nascimento ORCID https://orcid.org/0000-0001-8874-380X

Universidade Anhanguera-Uniderp, Brasil

E-mail: giovanascimento@gmail.com

Carla Letícia Gediel Rivero-Wendt ORCID https://orcid.org/0000-0001-6361-6927

Universidade Anhanguera-Uniderp, Brasil

E-mail: leticiagediel@gmail.com

Ana Luisa Miranda-Vilela

ORCID https://orcid.org/0000-0002-4762-8757

Pesquisador independente, Brasil

E-mail: analuisamv@uol.com.br

Doroty Mesquita Dourado

ORCID https://orcid.org/0000-0002-6164-6046

Universidade Anhanguera-Uniderp, Brasil

E-mail: douradod@uol.com.br

Gilberto Gonçalves Facco

ORCID https://orcid.org/0000-0002-6434-2398

Universidade Anhanguera-Uniderp, Brasil

E-mail: gilbertogfacco@hotmail.com

Vania Cláudia Olivon

ORCID https://orcid.org/0000-0001-6689-0972

Universidade Anhanguera-Uniderp, Brasil

E-mail: vania.olivon@gmail.com

Karla Rejane de Andrade Porto

ORCID https://orcid.org/0000-0002-6309-8696

Universidade Católica Dom Bosco, Brasil

E-mail: portokra@gmail.com

Antonia Railda Roel

ORCID https://orcid.org/0000-0002-6403-0554

Universidade Católica Dom Bosco, Brasil

E-mail: arroel@ucdb.br

Vania Lucia Brandão Nunes

ORCID https://orcid.org/0000-0001-5855-3589

Universidade Anhanguera-Uniderp, Brasil

E-mail: vlbnunes@terra.com.br

Ademir Kleber Morbeck Oliveira

ORCID https://orcid.org/0000-0001-9373-9573

Universidade Anhanguera-Uniderp, Brasil

E-mail: akmorbeckoliveira@gmail.com

Rosemary Matias

ORCID https://orcid.org/0000-0002-0154-1015

Universidade Anhanguera-Uniderp, Brasil

E-mail: rosematiasc@gmail.com

\begin{abstract}
We aimed to evaluate the phytochemical composition of the aqueous extract of leaves of Psychotria carthagenensis, and its possible toxicological effects at $200 \mu \mathrm{g} / \mathrm{Kg}$ on Rattus norvegicus. The aqueous extract was used for preliminary phytochemical analyses using standard procedures. After, male albino Wistar rats ( $N=6 /$ group) received
\end{abstract}


Research, Society and Development, v. 10, n. 4, e22810414059, 2021

(CC BY 4.0) | ISSN 2525-3409 | DOI: http://dx.doi.org/10.33448/rsd-v10i4.14059

by gavage for 15 consecutive days, infusions with fresh (FL) and dry leaf (DL) at $200 \mu \mathrm{g} / \mathrm{kg}$; controls received filtered water (negative) or clonazepam solution at $0.5 \mathrm{mg} / \mathrm{kg}$ (positive). Hematological analyses, determination of serum levels of aspartate aminotransferase (AST), alanine aminotransferase (ALT), urea, uric acid, total plasma protein (TPP), quantification of serum cholinesterase (AChE), and histological analyses of kidneys and liver were carried out. By the phytochemical analysis of the aqueous leaf extract, it was possible to detect the total phenols, flavonoids, tannins and alkaloids, the latter having been recorded for the species for the first time in this study. ALT and AST levels indicated an increase in these plasma enzymes, but histological analysis of kidneys and liver showed only slight changes. Inhibition of AChE levels was related mainly to alkaloids. The infusion showed the pharmacological potential of the plant as an alternative in the treatment of neurodegenerative diseases.

Keywords: Ayahuasca; AChE; Histopathology; Alkaloids; Biochemical markers; Hematology.

\section{Resumo}

Objetivamos avaliar a composição fitoquímica do extrato aquoso de folhas de Psychotria carthagenensis e seus possíveis efeitos toxicológicos a $200 \mu \mathrm{g} / \mathrm{Kg}$ em Rattus norvegicus. O extrato aquoso foi usado para análises fitoquímicas preliminares usando procedimentos padrão. Em seguida, ratos Wistar albinos machos $(\mathrm{N}=6 /$ grupo $)$ receberam por gavagem durante 15 dias consecutivos, infusões com folha fresca (FL) e seca (DL) a $200 \mu \mathrm{g} / \mathrm{kg}$; os controles receberam água filtrada (negativo) ou solução de clonazepam a $0,5 \mathrm{mg} / \mathrm{kg}$ (positivo). Foram realizadas análises hematológicas, determinação dos níveis séricos de aspartato aminotransferase (AST), alanina aminotransferase (ALT), ureia, ácido úrico, proteína plasmática total (TPP), quantificação da colinesterase sérica (AChE) e análises histológicas de rins e fígado. Pela análise fitoquímica do extrato aquoso da folha, foi possível detectar os fenóis totais, flavonoides, taninos e alcaloides, sendo estes últimos registrados para a espécie pela primeira vez neste estudo. Os níveis de ALT e AST indicaram um aumento nessas enzimas plasmáticas, mas a análise histológica dos rins e do fígado mostrou apenas ligeiras alterações. A inibição dos níveis de AChE foi relacionada principalmente aos alcaloides. A infusão mostrou o potencial farmacológico da planta como alternativa no tratamento de doenças neurodegenerativas.

Palavras-chave: Ayahuasca; AChE; Histopatologia; Alcaloides; Marcadores bioquímicos; Hematologia.

\section{Resumen}

Nuestro objetivo fue evaluar la composición fitoquímica del extracto acuoso de hojas de Psychotria carthagenensis y sus posibles efectos toxicológicos a $200 \mu \mathrm{g} / \mathrm{kg}$ sobre Rattus norvegicus. El extracto acuoso se utilizó para análisis fitoquímicos preliminares utilizando procedimientos estándar. Posteriormente, ratas Wistar albinas machos $(\mathrm{N}=$ 6/grupo) recibieron por sonda durante 15 días consecutivos, infusiones con hojas frescas (FL) y secas (DL) a 200 $\mu \mathrm{g} / \mathrm{kg}$; los controles recibieron agua filtrada (negativo) o una solución de clonazepam a $0,5 \mathrm{mg} / \mathrm{kg}$ (positivo). Se realizaron análisis hematológicos, determinación de niveles séricos de aspartato aminotransferasa (AST), alanina aminotransferasa (ALT), urea, ácido úrico, proteína plasmática total (TPP), cuantificación de colinesterasa sérica (AChE) y análisis histológico de riñón e hígado. Mediante el análisis fitoquímico del extracto acuoso de hoja, fue posible detectar el total de fenoles, flavonoides, taninos y alcaloides, siendo estos últimos registrados para la especie por primera vez en este estudio. Los niveles de ALT y AST indicaron un aumento en estas enzimas plasmáticas, pero el análisis histológico de los riñones y el hígado mostró solo cambios leves. La inhibición de los niveles de AChE se relacionó principalmente con los alcaloides. La infusión mostró el potencial farmacológico de la planta como alternativa en el tratamiento de enfermedades neurodegenerativas.

Palabras clave: Ayahuasca; AChE; Histopatología; Alcaloides; Marcadores bioquímicos; Hematología.

\section{Introduction}

Psychotria carthagenensis Jacq. (Rubiaceae), popularly known as "carne-de-vaca", "cafeeiro-do-mato", "erva-derato-branca" (Formagio et al., 2014) or "orelha-de-onça" (Dias Souza, Alcantara Morais Mendonça, \& Pessoa da Silva, 2013), is a shrub, 2-3 m high, which has wide distribution in Central and South America, from Costa Rica to Argentina(R. R. Faria, Ferrero, Navarro, \& Araujo, 2012; Koch, Silva, \& Silva, 2010; Vitarelli \& Santos, 2009). In Brazil, it is an endemic species (Magedans, Rodrigues-Corrêa, Costa, Matsuura, \& Fett-Neto, 2019; Reflora, 2020), popularly used in decoction by the people of the Amazonian Forest as one of the components of the hallucinogenic beverage ayahuasca, in religious rituals for social and medicinal purposes (Aronson, 2014; Formagio et al., 2014; Frecska, Bokor, \& Winkelman, 2016; Leal \& Elisabetsky, 1996; D.J. McKenna, 2004; Dennis J. McKenna, Towers, \& Abbott, 1984; Rivier \& Lindgren, 1972); for this last objective, as depurative and antirheumatic (Sanz-Biset, Campos-de-la-Cruz, Epiquién-Rivera, \& Cañigueral, 2009). Additionally, the species has undergone scientific research demonstrating the efficacy of its extracts as antioxidant (Formagio 
Research, Society and Development, v. 10, n. 4, e22810414059, 2021

(CC BY 4.0) | ISSN 2525-3409 | DOI: http://dx.doi.org/10.33448/rsd-v10i4.14059

et al., 2014), antifungal and antibacterial (Dias Souza et al., 2013), besides decreasing body temperature, which can be interpreted as an indication of central activity (Leal \& Elisabetsky, 1996; H. Yang, Zhang, Yang, \& Chen, 2016).

For the Psychotria genus, uses in traditional medicines, in the form of infusion/decoction, include treatment of bronchial (e.g. cough, bronchitis), gastrointestinal (e.g. ulcer and stomachache) and reproductive disorders (Calixto et al., 2016; Formagio et al., 2014). Some Psychotria species are also used against microbial infections (malaria, amoebiasis, viral and venereal diseases), and in cardiovascular and mental disorders (Calixto et al., 2016). External uses have also been described, such as applications for skin tumors, ulcers, ocular disorders (poultices), and baths for the treatment of fever, headache and earache (Formagio et al., 2014).

As the toxic potential of a herbal remedy depends on the pharmacological characteristics and dose levels of its bioactive constituents (De Smet, 1995), the preliminary investigation of chemical constituents provides knowledge of extracts and indicates the nature of the substances present (Souza, Sena, Maranho, Oliveira, \& Guimarães, 2008). For this reason, the interest in plants from the Psychotria genus has increased considerably in recent years, because it is well known for the biosynthesis of a number of bioactive alkaloids exhibiting interesting chemical traits and pharmacological activities (Calixto et al., 2016; Formagio et al., 2014; Magedans et al., 2019; Rivier \& Lindgren, 1972; H. Yang et al., 2016). It is also recognized as an abundant source of several other interesting natural products, such as coumarins, flavonoids, terpenoids, tannins and cyclic peptides (Calixto et al., 2016).

Considering the above, $P$. carthagenensis is one of these plants that deserves better investigation. Although several species of Psychotria have shown biological activity by presenting different types of secondary metabolites, especially alkaloids (Calixto et al., 2016; Moraes et al., 2011), until now, no alkaloids have been experimentally demonstrated for this species in scientific articles (Leal \& Elisabetsky, 1996; Lopes, Moreno, \& Henriques, 2000; Magedans et al., 2019; Porto, Henriques, \& Fett-Neto, 2009). Despite this, according to Rivier and Lindgren (1972), the dry weight of $P$. viridis and $P$. carthagenensis leaves revealed, respectively, $0.34 \%$ and $0.66 \%$ alkaloids, with substantial amounts of $\mathrm{N}, \mathrm{N}-$ dimethyltryptamine - DMT (99\% for both species), besides traces of N-monomethyltryptamine - MMT and $\beta$ carboline alkaloids such as 2-methyl-1,2,3,4-tetrahydro- $\beta$-carboline (MTHC) (Rivier \& Lindgren, 1972). Likewise, $P$. carthagenensis is used in the preparation of ayahuasca decoction as a substitute for Amazonian P. viridis (Porto et al., 2009), which has proven to have DMT alkaloid, a potent serotonergic hallucinogen (Aronson, 2014; Martins \& Nunez, 2015; D.J. McKenna, 2004; Dennis J. McKenna et al., 1984).

Acute ayahuasca administration and long-term consumption of this beverage do not seem to be seriously toxic to humans (dos Santos, 2013). However, it is known that the consumption of medicinal plants without evaluating their efficacy and safety can result in unexpected or toxic effects that may affect the physiology of different organs in the human body, mainly the liver and kidney, involved in the metabolism and excretion of chemical compounds (Idoh, Agbonon, Potchoo, \& Gbeassor, 2016).

Considering the group's interest in natural antioxidants and substances with activity in the central nervous system (CNS), mainly inhibitors of acetylcholinesterase (AChE), and the potential use of $P$. carthagenensis tea as an alternative treatment of CNS disorders, investigation is required to determine if in the chose dose at $200 \mu \mathrm{g} / \mathrm{Kg}$ P. carthagenensis extracts could be enabled to AChE inhibition without toxic effects on vital organs such as liver and kidneys. This chosen dose was based in the fact that higher doses of $P$. carthagenensis ethanol extract presented sedation and toxicity effects, even though having negative reaction for alkaloids in all tests (Leal \& Elisabetsky, 1996).

Therefore, the aim of the present study was to evaluate the phytochemical composition of the aqueous extract of leaves of $P$. carthagenensis, and its possible toxicological effects at $200 \mu \mathrm{g} / \mathrm{Kg}$ on Rattus norvegicus. To this end, 
Research, Society and Development, v. 10, n. 4, e22810414059, 2021

(CC BY 4.0) | ISSN 2525-3409 | DOI: http://dx.doi.org/10.33448/rsd-v10i4.14059

hematological parameters, determination of serum levels of aspartate aminotransferase (AST), alanine aminotransferase (ALT), urea, uric acid and total plasma protein (TPP), quantification of serum cholinesterase (AChE), and histological analyses of kidneys and liver were carried out.

\section{Methodology (TNR font 12 - left aligned)}

\subsection{Plant material and plant extract}

The collection of leaves of $P$. carthagenensis was carried out at the Reserve of the Federal University of Mato Grosso do Sul (UFMS), Campo Grande, Brazil. Immediately after collection, specimens with flowers and fruits were used for authentication purposes and, subsequently, the exsiccate was prepared and added to the herbarium collection (number 8514) by Professor Ademir Kleber Morbeck de Oliveira (PhD). For the purposes of collection and research, authorization was obtained to access genetic resources from the National System for Genetic Heritage and Associated Traditional Knowledge Management (SisGen), under registration number $\mathrm{N}^{\circ}$ A9EABCD.

After drying the leaves in a $40{ }^{\circ} \mathrm{C}$ air circulating greenhouse (MARCONI ${ }^{\circledR}$, Model MA35), they were triturated in a stainless-steel knife mill (MARCONI ${ }^{\circledR}$, Model MA048), and the aqueous extract of the botanical material was prepared, using $200 \mathrm{~g}$ of dry leaf powder to $1000 \mathrm{~mL}$ of solution (in distilled water). First, the solution was subjected to an ultrasound bath (UNIQUE ${ }^{\circledR}$, Model 1450) for 2 hours, followed by static maceration for 24 hours until the depletion of plant drug. Then, it was filtered, and the solvent was eliminated in a rotary evaporator to obtain the aqueous crude extract $\left(\mathrm{ExtH}_{2} \mathrm{O}\right)$.

\subsection{Phytochemical assays}

The aqueous extract was used for preliminary phytochemical analyses using standard procedures (Harborne, 1998; Matos, 2009). Analyses were performed in triplicate and results were compared to the control sample (aqueous extract), by observing the color alteration and precipitation. The reading of the results was adapted from Fontoura and co-workers, and the following were considered: negative reaction (-), discrete (turbidity) ( \pm ), weakly positive $(+)$, partially positive $(+ \pm)$, positive $(++)$, strongly positive $(++ \pm)$ and, high intensity $(+++)$, with a frequency of $0 ; 5 ; 15 ; 25 ; 50 ; 75$ and $100 \%$, respectively (Fontoura et al., 2015).

The confirmation of the chemical groups was performed by scanning the UV-visible spectrum using a $10 \mathrm{mg} / \mathrm{mL}$ aliquot of the crude aqueous extract; the absorption spectrum was determined in the 200 to $600 \mathrm{~nm}$ wavelength range.

\subsubsection{Determination of total phenols, flavonoids, condensed tannins and alkaloids}

The aqueous extract was used to quantify total phenols (TP), through Folin-Ciocalteu's method with modifications (Sousa et al., 2007), by using $100 \mathrm{mg}$ of the $\mathrm{ExtH}_{2} \mathrm{O}$ in methanol. The absorbance was measured in a spectrophotometer at 750 $\mathrm{nm}$, using a quartz cuvette. The analysis was performed by interpolating the absorbance of the samples against a calibration curve, constructed from the absorbance of increasing concentrations (ranging from 10 to $300 \mu \mathrm{g} / \mathrm{mL}$ ) of gallic acid (phenolic acid used as standard), and expressed as mg GAE (gallic acid equivalents).

To quantify flavonoids, the aqueous extract $(100 \mathrm{mg})$ was submitted to the methodology described by Do and collaborators (Do et al., 2014), using quercetin as standard (QE $=0.5 \mathrm{mg} / \mathrm{mL}$ ) to construct the calibration curve at concentrations of $0.04 ; 0.2 ; 0.4 ; 2 ; 4 ; 8 ; 12 ; 16$; and $20 \mu \mathrm{g} / \mathrm{mL}$. The analyses were performed by spectrophotometry at a wavelength of $420 \mathrm{~nm}$, in quartz cuvettes. 
Research, Society and Development, v. 10, n. 4, e22810414059, 2021

(CC BY 4.0) | ISSN 2525-3409 | DOI: http://dx.doi.org/10.33448/rsd-v10i4.14059

The determination of condensed tannins followed the methodology of Broadhurst and Jones (1978), using catechin as standard, and the results were expressed as catechin equivalents in mg per $100 \mathrm{~g}$ of extract (Broadhurst \& Jones, 1978).

The quantification of total alkaloids was carried out using $40 \mathrm{~mL}$ of aqueous extract, at a concentration of 1000 $\mu \mathrm{g} / \mathrm{mL}$, which was subsequently acidified to $\mathrm{pH}$ between 2.0 and 2.5 with $1 \mathrm{~mol} / \mathrm{L} \mathrm{HCl}$ and $4 \mathrm{~mL}$ of Dragendorff reagent and centrifuged at $2400 \mathrm{rpm}$ for 30 minutes. The supernatant was discarded, and the residue was treated with a solution containing $1 \mathrm{~mL}$ of ethyl alcohol; $2 \mathrm{~mL}$ of sodium sulfite (1\%) and centrifuged again (2400 rpm/30 minutes). Then, the supernatant was discarded, and the residue treated with concentrated nitric acid $(2 \mathrm{~mL})$. The solution was transferred to a $50 \mathrm{~mL}$ volumetric flask, and the volume was completed with distilled water. From this solution, an aliquot (1 mL) was used, $5 \mathrm{ml}$ of thiourea $3 \%$ (w/v) added and homogenized; the reading was performed on a spectrophotometer at $435 \mathrm{~nm}$. The solution of nitric acid and thiourea was used as a blank, and emetine $\left(\right.$ Merck $\left.^{\circledR}\right)$ was used as a standard, for which linearity was obtained between 40 and $200 \mu \mathrm{g} \mathrm{mL}$. The alkaloid content was expressed in mg per $100 \mathrm{~g}$ dry weight of the extract (Sreevidya \& Mehrotra, 2003).

\subsection{Biological assays with Wistar rats}

\subsubsection{Chemicals}

The anesthetics ketamin and xylazin were obtained as chloridrate. Ketamin, sold as Cetamin (ketamine hydrochloride 10\%), was obtained from Syntec (São Paulo, Brazil); and xylazine (injectable Anasedan) came from Ceva Animal Health Ltd (São Paulo, Brazil). Clonazepam tablet 0.5 mg (generic) was obtained from Medley (São Paulo, Brazil).

\subsubsection{Plant extracts}

For the biological assays, two extracts of $P$. carthagenensis were prepared daily by infusion in $50 \mathrm{ml}$ of distilled water each: the first containing $3 \mathrm{mg}$ of fresh leaf (FL), and the other containing $3 \mathrm{mg}$ of dry leaf (DL). Extracts were left to rest for 20 minutes for later oral administration, after filtration on cotton.

\subsubsection{Animals and experimental design}

Male albino Wistar rats (Rattus norvegicus) acquired from the bioterium (animal facility) of the Federal University of Mato Grosso do Sul, Campo Grande/Brazil, were housed in plastic cages with ventilation and air circulation, under standard conditions of $12 \mathrm{~h}$ dark/light cycle, controlled temperature $\left(23^{\circ}-25^{\circ} \mathrm{C}\right)$ and free access to food and filtered water. After a period of acclimatization of 15 days at the bioterium of the Agrarian Unit, Anhanguera-Uniderp University, the animals, aged 8 to 12 weeks and weighing $363.13 \pm 4.77 \mathrm{~g}$ at the beginning of the experiment, were randomly distributed in treatment groups.

The experimental design involved 24 rats randomly distributed in four groups ( $\mathrm{N}=6$ per group). Animals received orally (per os, p.o.) by gavage, the following treatments for 15 consecutive days: (1) $1 \mathrm{~mL}$ of filtered water (negative control, $\mathrm{C}-$ ); (2) $1 \mathrm{~mL}$ of clonazepam solution at $0.5 \mathrm{mg} / \mathrm{kg}$ (positive control, C+); (3) $1 \mathrm{~mL}$ of the infusion with fresh (FL) leaf at 200 $\mu \mathrm{g} / \mathrm{kg}$; and (4) $1 \mathrm{ml}$ of the infusion with dry leaf (DL) at $200 \mu \mathrm{g} / \mathrm{kg}$.

During the period of the experiment, animals were observed daily to check the effects of toxicity (such as weight loss, diarrhea, skin ulcers and deaths) and lethality. Body weights were also measured at the beginning and end of the treatment. At the end of the experiment, rats, then weighing $405.50 \pm 5.10 \mathrm{~g}$, were euthanized by ketamine and xylazine overdose (ketamine $300 \mathrm{mg} / \mathrm{kg}+$ xylazine $30 \mathrm{mg} / \mathrm{kg}$ ) intraperitoneally administered, according to the guidelines on Euthanasia of the Federal Council of Veterinary Medicine (CFMV) (Conselho Federal de Medicina Veterinária, 2013). 
Research, Society and Development, v. 10, n. 4, e22810414059, 2021

(CC BY 4.0) | ISSN 2525-3409 | DOI: http://dx.doi.org/10.33448/rsd-v10i4.14059

All animal handling and procedures were carried out according to the international practices for animal use and care and approved by the Animal Ethics Committee of Anhanguera-Uniderp University, reference number 3045.

\subsubsection{Hematological and biochemical analyses}

Before euthanasia, animals were anesthetized (ketamine $50 \mathrm{mg} / \mathrm{m}+$ xylazine $20 \mathrm{mg} / \mathrm{ml}$ ) for the collection of blood samples $(5 \mathrm{~mL})$ by cardiac puncture, to carry out the hematological analysis (globular volume - GV - or hematocrit, leukocytes and platelet counting), determination of the total plasma protein (TPP), and biochemical analyses of aspartate aminotransferase (AST), alanine aminotransferase (ALT), urea, uric acid, and serum cholinesterase.

Immediately after blood collection, an aliquot $(1 \mathrm{~mL})$ of blood samples was transferred to tubes containing EDTA as anticoagulant to carry out the hemogram. The remainder was transferred to tubes containing $0.9 \%$ normal saline (an isotonic concentration of sodium chloride, to avoid hemolysis and agglutination) (Blumberg et al., 2018; Jackson \& Derleth, 2000) and kept in an ice bath until ready to separate the plasma. Plasma was then separated by centrifugation at $2000 \mathrm{rpm}$, temperature of $5^{\circ} \mathrm{C}$, for 10 minutes for subsequent determination of GV, TPP and biochemical analyses.

Manual determination of globular volume (GV) was performed by the Strumia method, using a capillary tube of 1.0 mm internal diameter without anticoagulant and a micro-hematocrit centrifuge by Kubota ${ }^{\circledR}$, model 3220 (Silva et al., 2017). The leukocyte count was performed in a Neubauer chamber by Superior Marienfeld ${ }^{\circledR}$ (Silva et al., 2017), while for platelet counting both methods were used, counting in Neubauer chamber and blood smear slide observed under an optical microscope at 1000x magnification (G. Brecher \& Cronkite, 1950; G. Brecher, Schneiderman, \& Cronkite, 1953; Oliveira, Takadachi, Nonoyama, \& Barretto, 2003).

The determination of TPP was performed using manual refractometry (Melo et al., 2013). Analyses of liver and kidney function were performed by measuring ALT, AST, urea and uric acid levels, using a Bioplus $200^{\circledR}$ semi-automatic biochemical analyzer (São Paulo/Brazil) and Gold Analisa ${ }^{\circledR}$ kits (Belo Horizonte - MG/Brazil), with their appropriate reagents, protocols and controls. Absorbances were determined at $540 \mathrm{~nm}$.

\subsubsection{Quantification of serum cholinesterase}

The determination of serum cholinesterase in plasma was performed by a colorimetric system, using a BioSystems BTS $310^{\circledast}$ spectrophotometer (Campinas/SP, Brazil) and Doles Reagents kits (Goiânia/GO, Brazil), with their appropriate reagents, protocol, and controls.

The principle of the method is established in the colorimetric reaction, where serum cholinesterase hydrolyzes propionyl thiocholine, releasing thiocoline, which reacts with 5,5'-dithiobis-(2-nitrobenzoic acid) (DTNB, color reagent), leading to the formation of a yellow compound with absorption at $410 \mathrm{~nm}$ (Santos \& Mostardeiro, 2013). The enzyme and then the inhibitor were used to avoid false positives and confirm the result.

An initial sensitization test was carried out to establish the calibration factor, using 3 replicates, each one containing distilled water $(4.0 \mathrm{~mL})$, color reagent $(\mathrm{DTNB}, 3.0 \mathrm{~mL})$ and reconstituted powdered enzyme $(7 \mathrm{IU} / \mathrm{mL})$, accompanied by a blank control (negative) containing only water and color reagent under the same conditions. The material was homogenized and read in the blue or $410 \mathrm{~nm}$ range, and the spectrum was reset to zero with the white control.

The reading values obtained in absorbance were expressed as mean value, which was applied in the formulas below, having already defined the value of 7 as the units present in each $\mathrm{mL}$ of the enzyme solution.

Factor $(F)=\frac{7}{\text { Absorbance } P(\text { mean })}$ 
Cholinesterase (U.I./mL) $=\mathrm{T} \times$ Factor $(\mathrm{F})$

Expression of results in units IS:

Cholinesterase $(I U / L)=$ Cholinesterase $(I U / m L) \times 1000$

To construct the calibration curve, concentration values were set at $0 ; 1.875 ; 3.75 ; 7.0 ; 10.5 ; 14.0$; and $17.5 \mathrm{IU} / \mathrm{mL}$, considering the value for calculating the fixed calibration factor at $7 \mathrm{IU} / \mathrm{mL}$.

Enzymatic inhibition was established in a reaction containing the formulations at a concentration of $1 \mathrm{~g} / \mathrm{L}$, in triplicate for each product evaluated. The assays were carried out at a controlled temperature of $37^{\circ} \mathrm{C}$ and enzyme activity set at 7 $\mathrm{IU} / \mathrm{mL}$.

In the tests, $1.0 \mathrm{~mL}$ of propionyl thiocholine (used as a substrate), $3.0 \mathrm{~mL}$ of DTNB and $20 \mu \mathrm{L}$ of the sample were subjected to heating in a water bath for 2 minutes and 30 seconds to induce substrate breakdown and reaction with tested sample.

Soon after this, the material was homogenized and $20 \mu \mathrm{L}$ of enzymatic solution was added. A period of 30 seconds was allowed to pass before returning it to the water bath for another 30 seconds with the addition of $3.0 \mathrm{~mL}$ of reactioninhibiting solution. The material was again homogenized and read on a spectrophotometer at $410 \mathrm{~nm}$, immediately at the determined time of the reaction.

Each test battery was accompanied and conducted in conjunction with a positive standard containing substrate, color reagent, and enzyme, and another set as a negative standard containing color reagent and sample (blank). The equipment was previously zeroed with the blank.

The absorbance values found for the replicates (tests) were treated and compared in terms of values with establishment of the standard deviation(s) and the coefficient of variation (\%).

\subsubsection{Macroscopic examination and histological analyses of liver and kidneys}

After blood collection, kidneys and liver were surgically removed and first macroscopically examined in respect to their color, consistency, size and weight. The hepatosomatic index (HIS) was also calculated (Narra, 2016). Next, organs were prepared for histological evaluations. For this, they were fixed with $10 \%$ formalin for $24 \mathrm{~h}$, transferred to $70 \%$ ethanol, embedded in paraffin using the classic manual method of histological processing, cut to $3 \mu \mathrm{m}$ of thickness in a Leica RM2235 manual microtome (Leica Microsystems, Nussloch, Germany) and stained with hematoxylin-eosin (HE). Sections were photographed with an MC 80 DX camera coupled to a Zeiss Axiophot light microscope (Carl Zeiss).

\subsection{Statistical analyses}

Statistical analysis was carried out using IBM SPSS Statistics version 22.0. Biological data were expressed as mean \pm SEM (standard error of mean) and values of $p<0.05$ were considered statistically significant. The continuous variables were tested for normal distribution with Shapiro-Wilk. Differences among the analyzed groups were investigated through ANOVA or Kruskal-Wallis test (when the data were not normally distributed). For significant ANOVA results, Tukey's post-hoc test was chosen to carry out 2-to-2 comparisons between the treatments. For significant Kruskal-Wallis results, the Mann-Whitney $\mathrm{U}$ test was performed to verify differences between the treatments (2-to-2 comparisons). The Paired T-Test was also used to verify differences between the initial and final body weight. 
Research, Society and Development, v. 10, n. 4, e22810414059, 2021

(CC BY 4.0) | ISSN 2525-3409 | DOI: http://dx.doi.org/10.33448/rsd-v10i4.14059

For the biochemical dosages of AST, ALT, urea and uric acid, statistical analysis was carried out using GraphPad Prism version 6, with $p<0.05$ considered significant. Differences among the groups were analyzed by ANOVA, followed by the Newman-Keuls post-hoc test.

\section{Results and Discussion}

\subsection{Phytochemicals}

The phytochemical analysis of the aqueous extract from P. carthagenensis leaves indicated the presence of phenolic compounds, anthraquinones, and steroids $(+++=100 \%)$, flavonoids and alkaloids $(++ \pm=75 \%)$ tannins and reducing sugars $(++=50 \%)$, triterpenes and saponins $(+ \pm=25 \%)$. The majority classes of secondary metabolites in the extract, observed in the UV-visible spectra, showed maximum absorption between 220 and $420 \mathrm{~nm}$, characteristics of phenolic compounds (280 nm), flavonoids (330 and $380 \mathrm{~nm}$ ), and alkaloids (220 and $420 \mathrm{~nm}$ ).

This chemical profile is in accordance with the classes of secondary metabolites described for the Psychotria genus (Calixto et al., 2016; H. Yang et al., 2016), and even though HPLC was not used, our work is a pioneer not only for being the first to describe a whole chemical profile study with $P$. carthagenensis, but also to demonstrate the presence of alkaloids for this species.

The total phenol content of the aqueous extract of $P$. carthagenensis leaves was of $170.00 \pm 0.01 \mathrm{mg} \mathrm{g}^{-1}$, of flavonoids of $78.82 \pm 0.016 \mathrm{mg} \mathrm{g}^{-1}$ and tannins, $35.45 \pm 0.156 \mathrm{mg} \mathrm{g}^{-1}$, values considered high when compared with leaf extracts from other species of the Psychotria genus (Corrêa, Soares, \& Fett-Neto, 2008; Formagio et al., 2014); also corroborating its highest reported antioxidant activity (Formagio et al., 2014).

As regards anthraquinones, besides their laxative or purgative effect (Simpson \& Amos, 2017), which would justify the medicinal use of the species as depurative (Sanz-Biset et al., 2009), these compounds also possess antifungal and antiviral activities (Simpson \& Amos, 2017), which could at least partially justify some of the pharmacological activities reported for $P$. carthagenensis (Dias Souza et al., 2013).

Steroids and terpenoids have also been reported for other Psychotria genus species (Calixto et al., 2016; Lopes et al., 2000; H. Yang et al., 2016), corroborating our findings. Moreover, for $P$. carthagenensis, the presence of triterpenes, $\beta$ sitosterol, and ursolic acid has been demonstrated in in vitro cultures (Lopes et al., 2000), where ursolic acid has been indicated as one of active compounds with cytotoxic activity for several types of cultured human cancer cells (Lopes et al., 2000).

Furthermore, triterpenoid saponins have also been isolated from Psychotria species, and in vitro bioassays have shown that all concentrations of these triterpenoids that were tested reduced the viability of three human cancer cell types (Zhang et al., 2013). These bioactive compounds, together with the accumulation of soluble tannins in P. carthagenensis (Magedans et al., 2019), may be responsible for this species being considered toxic by the indigenous Makuna tribe of northwestern Amazonia (Leal \& Elisabetsky, 1996).

Furthermore, in phytochemical screening of plants native to the Uruguay River, in which $P$. carthagenensis was included, the presence of polyphenols, flavonoids, triterpenes/steroids, low molecular weight terpenes, saponins, and tannins was detected for this species (Bertucci, Haretche, Olivaro, \& Vázquez, 2008), corroborating the chemical profile obtained in the present article.

However, until now, no alkaloids have been experimentally demonstrated for P. carthagenensis (Leal \& Elisabetsky, 1996; Lopes et al., 2000; Magedans et al., 2019; Porto et al., 2009), although it is used in the preparation of ayahuasca decoction instead of $P$. viridis (Porto et al., 2009), which has been proven to have DMT alkaloid, a potent serotonergic 
Research, Society and Development, v. 10, n. 4, e22810414059, 2021

(CC BY 4.0) | ISSN 2525-3409 | DOI: http://dx.doi.org/10.33448/rsd-v10i4.14059

hallucinogen (Aronson, 2014; Martins \& Nunez, 2015; D.J. McKenna, 2004; Dennis J. McKenna et al., 1984). Indeed, extraction will depend on the affinity of the solute for the extractor solvent (Azwanida, 2015). In our findings, the alkaloid content was $56.28 \pm 2.39 \mathrm{mg} \mathrm{g}^{-1}$. So, $\mathrm{EtOH}, \mathrm{CHCl}_{3}$, acetone and $\mathrm{EtOH} / \mathrm{H}_{2} \mathrm{O}$ extracts of leaves, instead of using the decoction or infusion method, could explain the findings that show no alkaloids for P. carthagenensis (Leal \& Elisabetsky, 1996). Moreover, various genetic, ontogenic, morphogenetic and environmental factors can influence the biosynthesis and accumulation of plant secondary metabolites (SMs) (L. Yang et al., 2018), including development/growth stages of the plant on a broader spectrum (Shukla \& Singh, 2001). There are also a variety of environmental factors such as light, temperature, soil water, soil fertility and salinity, where for most plants, a change in an individual factor may alter the content of SMs even if other factors remain constant (L. Yang et al., 2018).

In Brazil, P. carthagenensis is commonly found not only in areas of moist soil near water bodies (R. R. Faria \& Araujo, 2015), but also on sandy or clayey soils (R. Faria \& Lima, 2008; Koch et al., 2010) of the phytogeographic domains Amazon, Caatinga, Cerrado, Atlantic Forest, Pampa and Pantanal (Reflora, 2020). Consequently, as these plants are distributed in different environments, from sea level to $600 \mathrm{~m}$ altitude, it is possible to observe not only wide morphological variation between the populations of each of these regions (Vitarelli \& Santos, 2009), but also differences in phytochemicals, since environmental factors may influence types and contents of bioactive substances (Liu et al., 2016; L. Yang et al., 2018).

\subsection{Biological assays with Wistar rats}

\subsubsection{General animal health status}

There were no weight losses, although the experimental groups treated with fresh and dry leaves of P. carthagenensis at $200 \mu \mathrm{g} / \mathrm{Kg}$ showed significant differences in body weight before treatments, compared to the negative control (Table 1).

Table 1. Initial and final body weight of Wistar rats, after 15 days of treatments using negative and positive controls and extracts of fresh and dried leaves of $P$. carthagenensis, collected in Campo Grande, Mato Grosso do Sul, difference in respect to the initial weight (weight gain), and mean daily water consumption.

\begin{tabular}{|c|c|c|c|c|}
\hline Treatment & $\begin{array}{l}\text { Inicial body weigth } \\
\text { (g) }\end{array}$ & $\begin{array}{l}\text { Final body weigth } \\
\text { (g) }\end{array}$ & $\begin{array}{l}\text { Weight gain } \\
(\%)\end{array}$ & $\begin{array}{l}\text { Mean water consumption daily } \\
(\mathrm{mL})\end{array}$ \\
\hline Negative Control (C-) & $340.00 \pm 7.19$ & $384.03 \pm 8.17^{\neq}$ & $12.95 \pm 0.06$ & $41.13 \pm 1.11$ \\
\hline Positive Control $(\mathrm{C}+)$ & $360.00 \pm 7.75$ & $408.37 \pm 12.11^{\neq}$ & $13.36 \pm 1.33$ & $41.24 \pm 1.20$ \\
\hline $\begin{array}{l}\text { Fresh leaves (FL) } \\
\text { extract }\end{array}$ & $370.00 \pm 5.32^{* a}$ & $410.70 \pm 5.91^{\neq}$ & $11.00 \pm 0.00^{* a . b}$ & $40.68 \pm 0.79$ \\
\hline $\begin{array}{l}\text { Dry leaves (DL) } \\
\text { extract }\end{array}$ & $382.50 \pm 9.20^{* a}$ & $418.92 \pm 9.78^{\neq}$ & $9.54 \pm 0.46^{* a . b . c}$ & $38.38 \pm 1.60$ \\
\hline P-values & 0.005 & 0.079 & 0.000 & 0.3101 \\
\hline
\end{tabular}

*The data correspond to the mean \pm standard error of mean $($ SEM). Weight gain $=$ final weigh - initial weight/initial weight $\mathrm{x}$ 100 (Angelo and Jorge 2007). P-values of initial and final body weight, and mean water consumption daily were generated by ANOVA, while p-values of weight gain, by the Kruskall-Wallis test. The superscript letters indicate significant differences between 2 groups, detected by the Tukey's test or the Mann-Whitney U test, with a= significant compared to negative control; $\mathrm{b}=$ significant compared to the positive control; and $\mathrm{c}=$ significant compared to the FL group. Asterisks indicate significant differences at $* \mathrm{p}<0.05$. The symbol $\neq$ indicates significant differences between the initial and final body weight, detected by the Paired T-Test.

Source: Authors 
Research, Society and Development, v. 10, n. 4, e22810414059, 2021

(CC BY 4.0) | ISSN 2525-3409 | DOI: http://dx.doi.org/10.33448/rsd-v10i4.14059

On the other hand, even though there were significant weight gains by all groups at the end of the experiment, these were significantly lower in those groups treated with both extracts of $P$. carthagenensis, mainly with the dry extract of the leaves. This was already expected, because several compounds with anti-obesity potential obtained from plants have been identified in species of the Psychotria genus, including flavonoids (quercetin), phenols (4-hydroxybenzoic acid), phytosterols ( $\beta$-sitosterol, stigmasterol), and terpenoids (betulinic acid) (Calixto et al., 2016; Sharma \& Kanwar, 2018).

Thus, our results for the animals' body weight gain suggest that the extracts, in the concentration of $200 \mu \mathrm{g} / \mathrm{mL}$, were not toxic, corroborating the results of hematology and also our macroscopic, histological and biochemical findings.

\subsubsection{Hematology}

The only significant differences with respect to the negative control concerned the increased total leukocytes (white blood cells; WBC) in the positive control $(\mathrm{p}=0.016)$ group (Table 2). However, this increase was not related to any specific type of leukocyte.

Table 2. Hematological analyses of Wistar rats after 15 days of treatments using negative and positive controls and extracts of fresh and dried leaves of $P$. carthagenensis, collected in Campo Grande, Mato Grosso do Sul.

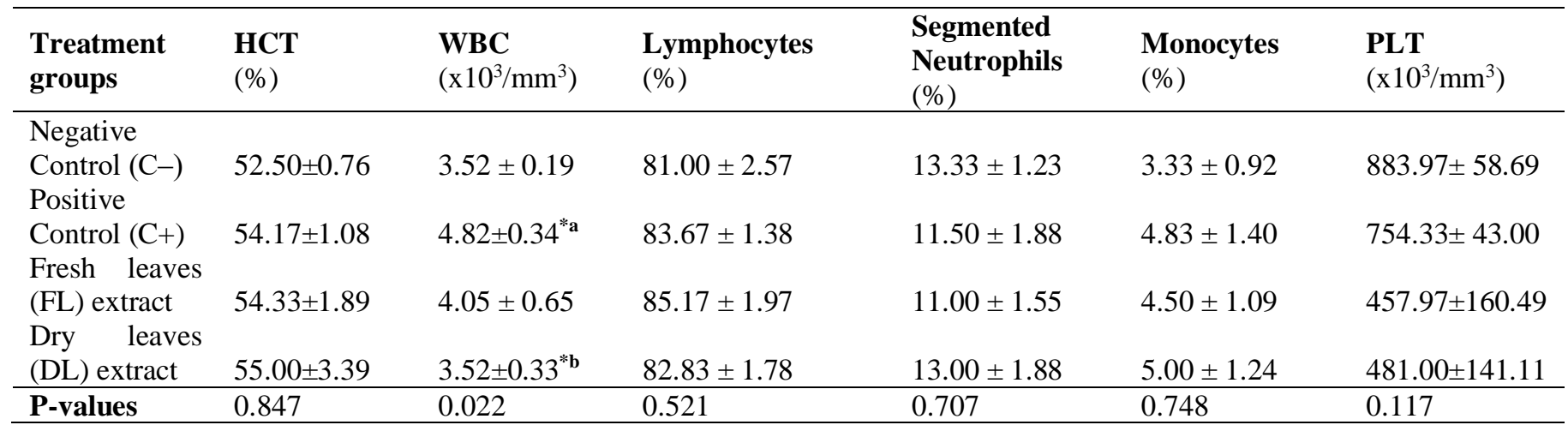

Data were expressed as mean \pm SEM (standard error of mean). HCT= globular volume $(\mathrm{GV})$ or hematocrit; WBC $=$ White Blood Cells; PLT = platelets. P-values of HCT, Lymphocytes, Segmented Neutrophils and Monocytes were generated by ANOVA, while p-values of WBC and PLT were generated by the Kruskall-Wallis test. The superscript letters indicate significant differences between 2 groups, detected by the Mann-Whitney $U$ test, with a= significant compared to negative control; $b=$ significant compared to the positive control. Asterisks indicate significant differences at $* \mathrm{p}<0.05$.

Source: Authors.

\subsubsection{Macroscopic examination of kidneys and liver}

No changes in the macroscopic aspect of organs were observed in the animals; all groups showed normal appearance (Table 3). Likewise, the hepatosomatic index (HSI) of livers exposed to fresh and dry leaf extracts of P. carthagenensis did not show significant differences in relation to the control. The HSI is expressed as the relative weight of the liver as percent of the total body mass and is a usual biomarker to detect possible effects and injuries caused by environmental stressors (Morado, Araújo, \& Gomes, 2017; Narra, 2016). The liver is a detoxifying organ and, when performing its function, it is more affected when under the action of some toxic substance, which may result in alteration in HSI. Thus, we can infer that the aqueous extracts of $P$. carthagenensis in the used dosage were not toxic and did not cause a stressful effect on the liver of the rats. 
Table 3. Measurements and weight of kidneys and liver, and hepatosomatic index (HSI) of Wistar rats after 15 days of treatments using negative and positive controls and extracts of fresh and dried leaves of P. carthagenensis, collected in Campo Grande, Mato Grosso do Sul.

\begin{tabular}{|c|c|c|c|c|c|c|c|c|c|c|}
\hline \multirow{2}{*}{$\begin{array}{l}\text { Treatment } \\
\text { groups }\end{array}$} & \multicolumn{3}{|c|}{ Right kidney } & \multicolumn{3}{|c|}{ Left kidney } & \multicolumn{4}{|l|}{ Liver } \\
\hline & $\begin{array}{l}\text { Long. } \\
\text { (cm) }\end{array}$ & $\begin{array}{l}\text { Trans. } \\
(\mathrm{cm})\end{array}$ & W (g) & $\begin{array}{l}\text { Long. } \\
\text { (cm) }\end{array}$ & $\begin{array}{l}\text { Trans. } \\
\text { (cm) }\end{array}$ & W. (g) & $\begin{array}{l}\text { Long. } \\
\text { (cm) }\end{array}$ & $\begin{array}{l}\operatorname{Trans}(\mathbf{c} \\
\mathrm{m})\end{array}$ & W.(g) & $\begin{array}{l}\text { HSI } \\
(\%)\end{array}$ \\
\hline $\begin{array}{l}\text { Negative } \\
\text { Control } \\
(\mathrm{C}-)\end{array}$ & $\begin{array}{l}1.72 \pm \\
0.11\end{array}$ & $\begin{array}{l}0.83 \pm \\
0.09\end{array}$ & $\begin{array}{l}1.52 \pm \\
0.05\end{array}$ & $\begin{array}{l}1.58 \pm \\
0.09\end{array}$ & $\begin{array}{l}0.80 \pm \\
0.08\end{array}$ & $\begin{array}{l}1.71 \pm \\
0.04\end{array}$ & $\begin{array}{l}4.98 \pm \\
0.20\end{array}$ & $\begin{array}{l}3.95 \pm \\
0.35\end{array}$ & $\begin{array}{l}13.05 \pm \\
0.38\end{array}$ & $\begin{array}{l}3.95 \pm \\
0.35\end{array}$ \\
\hline $\begin{array}{l}\text { Positive } \\
\text { Control } \\
(\mathrm{C}+)\end{array}$ & $\begin{array}{l}1.73 \\
\pm 0.07\end{array}$ & $\begin{array}{l}0.85 \pm \\
0.06\end{array}$ & $\begin{array}{l}1.59 \pm \\
0.06\end{array}$ & $\begin{array}{l}1.62 \pm \\
0.07\end{array}$ & $\begin{array}{l}0.90 \pm \\
0.06\end{array}$ & $\begin{array}{l}1.63 \pm \\
0.04\end{array}$ & $\begin{array}{l}5.10 \pm \\
0.14\end{array}$ & $\begin{array}{l}3.60 \pm \\
0.18\end{array}$ & $\begin{array}{l}13.11 \pm \\
0.43\end{array}$ & $\begin{array}{l}3.60 \pm \\
0.18\end{array}$ \\
\hline $\begin{array}{l}\text { Fresh leaves } \\
\text { (FL) extract }\end{array}$ & $\begin{array}{l}1.60 \pm \\
0.10\end{array}$ & $\begin{array}{l}0.77 \pm \\
0.09\end{array}$ & $\begin{array}{l}1.54 \pm \\
0.12\end{array}$ & $\begin{array}{l}1.55 \pm \\
0.09\end{array}$ & $\begin{array}{l}0.80 \\
\pm 0.05\end{array}$ & $\begin{array}{l}1.48 \pm \\
0.08\end{array}$ & $\begin{array}{l}5.03 \pm \\
0.28\end{array}$ & $\begin{array}{l}3.55 \pm \\
0.26\end{array}$ & $\begin{array}{l}12.53 \pm \\
0.74\end{array}$ & $\begin{array}{l}3.55 \pm \\
0.26\end{array}$ \\
\hline $\begin{array}{l}\text { Dry leaves } \\
\text { (DL) extract }\end{array}$ & $\begin{array}{l}1.73 \pm \\
0.09\end{array}$ & $\begin{array}{l}0.77 \pm \\
0.06\end{array}$ & $\begin{array}{l}1.58 \pm \\
0.11\end{array}$ & $\begin{array}{l}1.57 \pm \\
0.07\end{array}$ & $\begin{array}{l}0.95 \pm \\
0.02^{* \mathrm{c}}\end{array}$ & $\begin{array}{l}1.63 \pm \\
0.09^{* c}\end{array}$ & $\begin{array}{l}5.45 \pm \\
0.19\end{array}$ & $\begin{array}{l}3.48 \pm \\
0.16\end{array}$ & $\begin{array}{l}13.63 \pm \\
0.85\end{array}$ & $\begin{array}{l}3.48 \pm \\
0.16\end{array}$ \\
\hline P-values & 0.719 & 0.701 & 0.717 & 0.893 & 0.104 & 0.149 & 0.411 & 0.571 & 0.349 & 0.258 \\
\hline
\end{tabular}

Data were expressed as mean \pm SEM (standard error of mean). HSI = [liver weigh (g)/whole body weight (g)] x 100 . For kidneys, p-values were generated by the Kruskall-Wallis test, while for liver, p-values of the measurements (longitudinal and transversal) were generated by ANOVA, and p-value of weigh and HSI was generated by the Kruskall-Wallis test. The superscript letters indicate significant differences between 2 groups, detected by the Tukey's test or the Mann-Whitney U test, with $a=$ significant compared to negative control; $b=$ significant compared to the positive control; and $c=$ significant compared to the FL group. Asterisks indicate significant differences at $* \mathrm{p}<0.05$. Long.=longitudinal, Trans. $=$ transversal, W. $=$ weight. Source: Authors.

\subsubsection{Histopathological analyses of kidneys and liver}

Microscopically, kidneys of all animals also proved well preserved, with renal corpuscles (glomeruli) and contorted proximal and distal tubules intact, although slight changes could be observed in the treated groups. The negative control group (C-) showed glomerulus and renal tubules with habitual morphological aspect (Figure 1A), while in the positive control (C+), it was possible to observe dilated tubular light (Figure 1B). Furthermore, in those groups treated with extracts of $P$. carthagenensis, vascular congestion inside small blood vessels (Figure 1C) was observed in the group treated with fresh leaves (FL). In contrast, a reduction in Bowman's capsule space and cell tumefaction with a decrease in tubular lumen were observed in the group treated with dry leaves (DL) (Figure 1D). Moreover, the presence of inflammatory infiltrates, areas of calcification and necrosis was not observed in the analyzed samples.

In spite of this, normality following requirements: (1) glomeruli, formed by blood capillaries, endothelial and mesangial cells without histological changes; (2) Bowman's capsules intact, covered with simple, squamous epithelium; (3) renal tubules, covered with cubic or polyhedral cells, and presenting eosinophilic cytoplasm and a rounded nucleus; and (4) in the medullary region, the Henle loop, next to the capillaries and collecting tubules (with well-defined cytoplasm and spherical nucleus), with a usual aspect for these structures. 
Research, Society and Development, v. 10, n. 4, e22810414059, 2021

(CC BY 4.0) | ISSN 2525-3409 | DOI: http://dx.doi.org/10.33448/rsd-v10i4.14059

Figure 1. Light photomicrograph: (A) Histological section of kidney from the negative control group (C-) showing Bowman's capsule space (arrowhead) and renal tubules (arrows). (B) Kidney histological section of positive control group (C+) showing dilated tubular lumen (arrow). (C) Histological sections of kidney from group treated with fresh leaves (FL) of $P$. carthagenensis, showing small vascular congestion (arrow). (D) Histological section of kidney from group treated with dry leaves (DL), showing decrease in Bowman's capsule space and in tubular lumen (arrow). Hematoxylin and Eosin staining. 400x magnification.
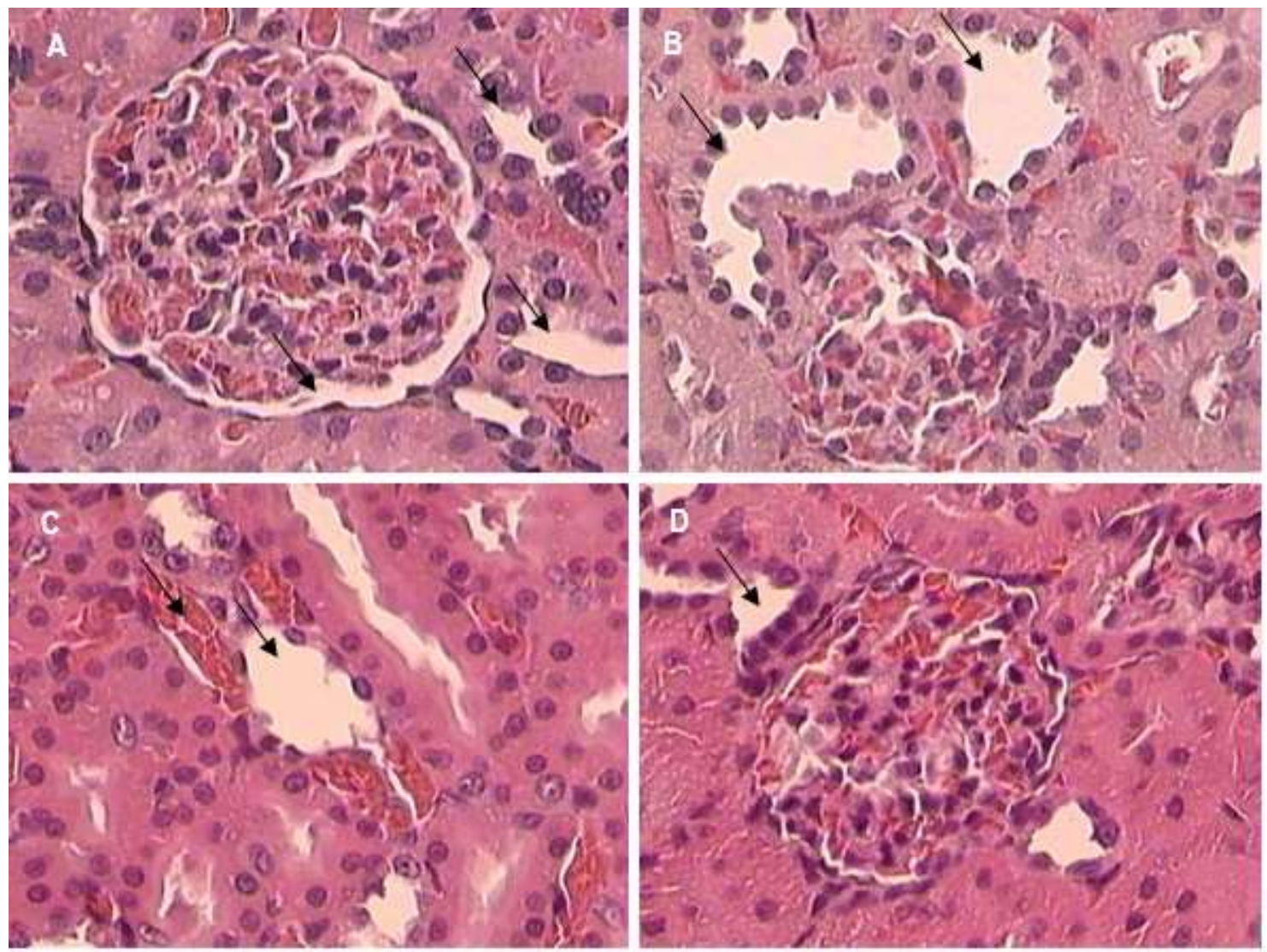

Source: Authors.

As regards the liver, hepatocytes and normal histological patterns were generally observed, such as (1) good state of conservation; (2) homogeneity of aspect; (3) identification of intact liver lobules, intact portal space and well-defined hepatic veins; and (4) sinusoid cords present intact, converging into the central-lobular vein; except for mild vascular congestion with protein precipitation on the periphery of the blood vessel in animals treated with dry leaf extract (DL group) (Figure 2). In the sinusoid capillaries, the presence of some red blood cells was also understood as normal. 
Research, Society and Development, v. 10, n. 4, e22810414059, 2021

(CC BY 4.0) | ISSN 2525-3409 | DOI: http://dx.doi.org/10.33448/rsd-v10i4.14059

Figure 2. Light photomicrograph. (A) Histological section of liver from negative control group (C-) showing nuclei of hepatocytes with usual morphology (arrows). Histological section of liver from positive control group $(\mathrm{C}+)$ showing portal triad (Virchow) with normal pattern (asterisk). (C) Histological sections of liver from group treated with fresh extract (FL) of P. carthagenensis, showing nuclei of hepatocytes with usual morphology (arrows). (D) Histological section of liver in the group treated with dry leaf extract (DL) of $P$. carthagenensis, showing vascular congestion and protein precipitation in the periphery (arrow). Hematoxylin and Eosin (HE) staining. 200x magnification.

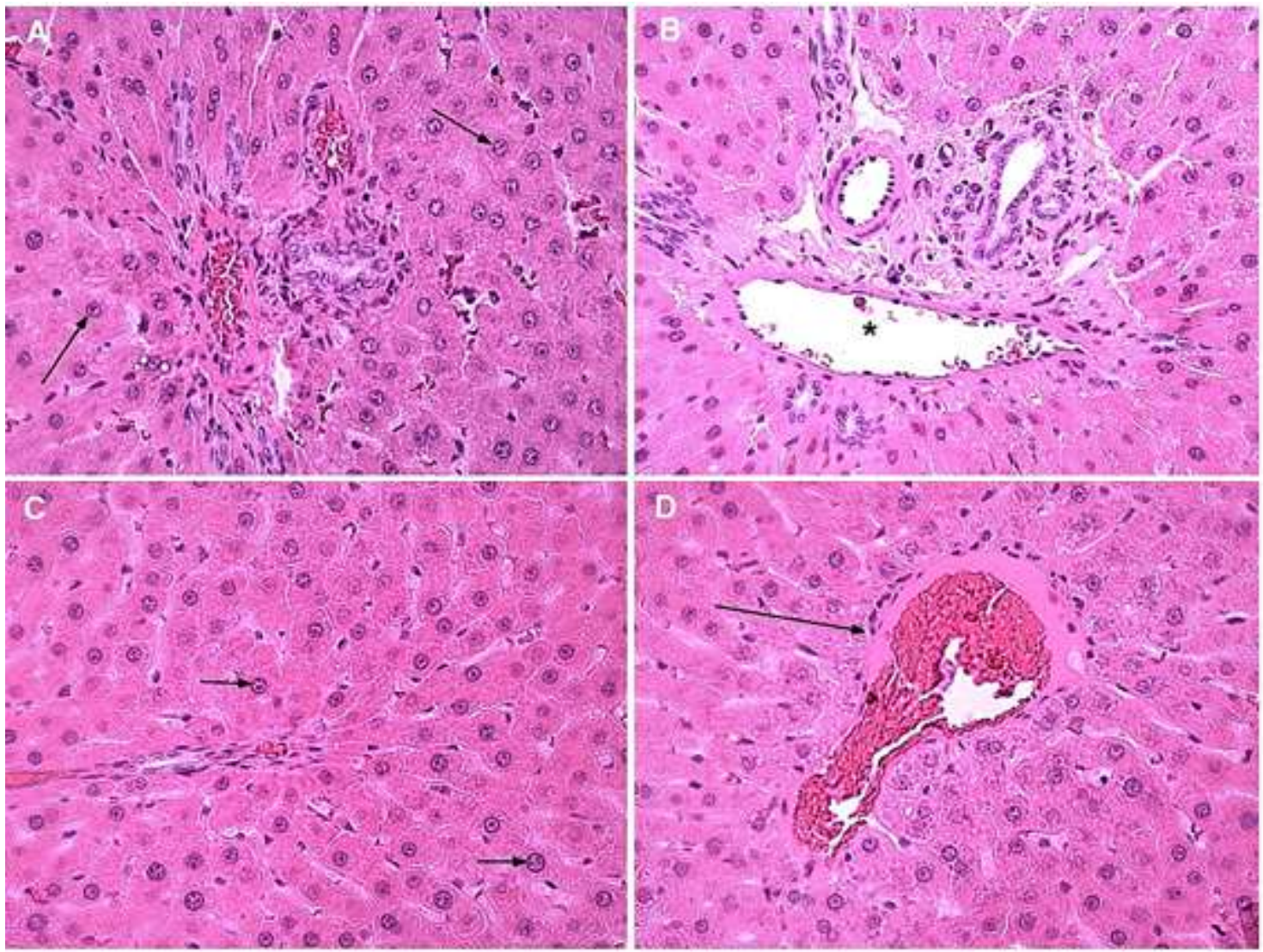

Source: Authors.

No inflammatory infiltrate, areas of degeneration and necrosis were observed in any of the groups, although slight changes could be observed in the group treated with dry leaves (DL), corroborating the findings of the biochemical analysis of AST and ALT (Figure 3). This also corroborated our previous suggestions that, although the extracts, in the concentration of $200 \mu \mathrm{g} / \mathrm{mL}$, were not toxic, the dried plant extract (DL) would have a greater number of active compounds than the fresh leaf extract (FL).

Mild hepatic and/or renal histopathological alterations have been reported in Wistar rats administered ayahuasca tea at doses by gavage (equal or greater than $4 \mathrm{x}$ ) higher than those used in religious rituals $(0.31 \mathrm{mg} / \mathrm{Kg}, \mathrm{DMT}, 3.3 \mathrm{mg} / \mathrm{Kg}$ harmonine and $0.26 \mathrm{mg} / \mathrm{Kg}$ of harmaline), for 4 (Acharezzi, Tangerino, Sperandio, Mestriner, \& Malfará, 2015) or 14 (Morais, 2014) days. These liver changes may be associated with the hepatic metabolism of DMT, which orally undergoes degradation by MAO (monoaminoxidase enzyme) present in the liver (Buckholtz \& Boggan, 1977), whenever DMT is ingested along with MAO-A inhibitors, such as in the case of ayahuasca tea admixtures (Simão et al., 2019).

Even though ayahuasca involves several active ingredients from two plants (Banisteriopsis caapi, containing the $\beta$ carboline alkaloids, mainly harmine and harmaline, powerful inhibitors of MAO; and $P$. viridis, whose leaves contain the 
hallucinogen DMT) (Gambelunghe, Aroni, Rossi, Moretti, \& Bacci, 2008; Simão et al., 2019), and our work used P. carthagenensis, this species is used in the preparation of ayahuasca decoction as a substitute for P. viridis (Porto et al., 2009).

Although this work has failed to verify the main phytochemical compounds of $P$. carthagenensis by HPLC, mass spectroscopy or another more modern technique, this is the first work reporting both the phytochemical (including presence of alkaloids) and biological assays of aqueous extract of $P$. carthagenensis.

\subsubsection{Biochemical analyses of ALT and AST}

As shown in Figure 3, a significant increase in plasma levels of AST and ALT was observed in the groups treated with the extract of fresh and dried leaves of $P$. carthagenensis in comparison to the controls, biochemically revealing hepatocellular impacts.

Figure 3. Evaluation of the effects on the plasma levels of AST (A) and ALT (B) after 15 days of clinical trial using negative and positive controls, and extracts of fresh (FL) and dried (DL) leaves of P. carthagenensis, collected in Campo Grande, Mato Grosso do Sul. The plasma concentrations were evaluated with assays using Gold Analisa kits. Bar graphs were expressed as SEM (standard error of mean) of $\mathrm{mg} / \mathrm{dL}$ of plasma. Asterisks indicate significant differences $(* \mathrm{p}<0.05)$ compared to the negative control (ANOVA followed by Newman Keuls).
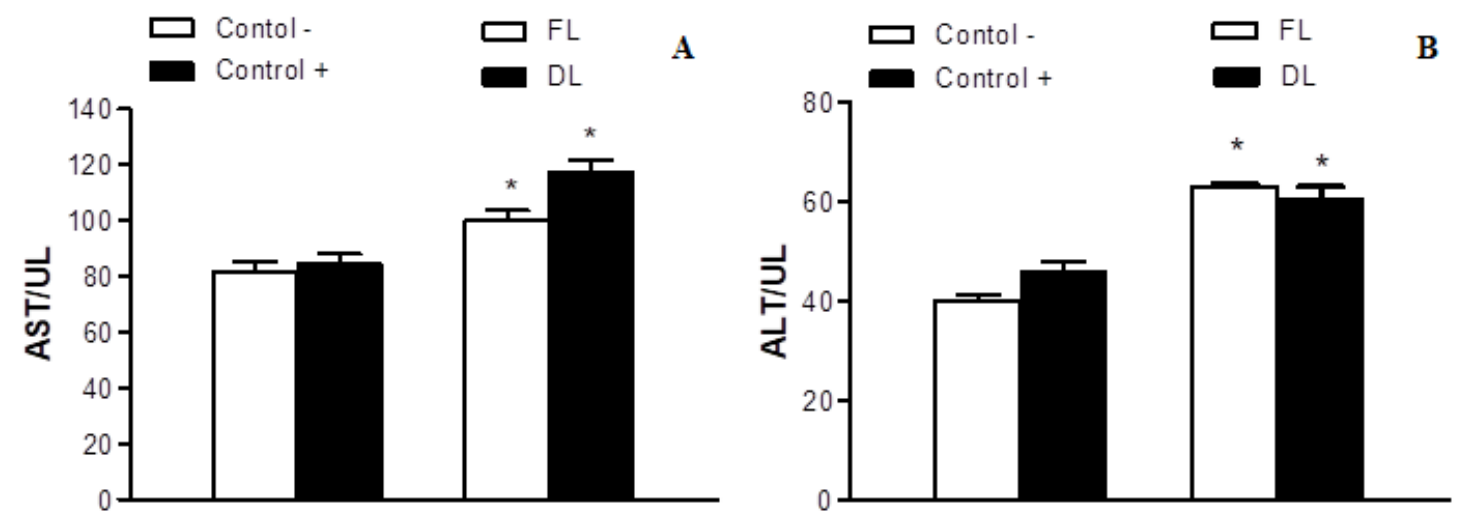

Source: Authors.

Liver damage, both in basic toxicology research and in preclinical toxicity testing, is usually evaluated by plasma/serum biochemical parameters prior to confirmation by histopathology. Following hepatocellular injury, for example, the plasma hepatic enzymes, such AST and ALT, overflow from the membrane into peripheral blood, where they can be measured (Ramaiah, 2007). Although the interpretation of the results can be complex, because the enzymes are unspecific and may be affected by diseases or injuries in other organs (Moreira, Souza, Barini, Ara $\tilde{A}^{\text {ojo, }}$ \& Fioravanti, 2012), ALT is relatively specific for the hepatocytes of rats (there is high activity of this enzyme in the hepatocellular cytoplasm of these animals) compared to AST, which is noted in higher levels in a variety of tissues such as liver, muscle and red blood cells (Ramaiah, 2007). On the other hand, ALT is cytosolic and AST is both cytosolic and mitochondrial (Ramaiah, 2007). So, any tissue injury or disease affecting the liver parenchyma may result in the release of a greater amount of these enzymes, mainly AST, into the bloodstream, with a consequent increase in their plasma levels (Bruce, Todd, \& Ledune, 1958; Ramaiah, 2007). 
Regarding the hepatic status, clinical biochemistry may correspond to a change, but it does not reveal the causes, types, or the distribution of the injury. Thus, histopathological analysis is essential to obtain consistent information about the hepatic histopathology (Moreira et al., 2012). In this context, results of AST and ALT corroborate the mild changes observed in the group treated with dry leaf extract (DL). This is because changes in plasma transaminase activity have been found to be very sensitive indices of liver injuries (Almersjö et al., 1968), and following acute hepatocellular injury, there will be moderate to marked increase in both plasma ALT and AST (Ramaiah, 2007).

\subsubsection{Biochemical analyses of urea and uric acid}

Results demonstrated a significant reduction in urea levels in respect to the negative control in the groups treated with the extract of fresh (FL) and dried (DL) leaves of $P$. carthagenensis (Figure 4A). In respect to the uric acid, no significant difference was detected (Figure 4B).

Figure 4. Evaluation of the effects on the plasma levels of urea (A) and uric acid (B) after 15 days of clinical trial using negative and positive controls, and extracts of fresh (FL) and dried (DL) leaves of P. carthagenensis, collected in Campo Grande, Mato Grosso do Sul. The plasma concentrations were evaluated with assays using Gold Analisa kits. Bar graphs were expressed as SEM (standard error of mean) of $\mathrm{mg} / \mathrm{dL}$ of plasma. Asterisks indicate significant differences $(* \mathrm{p}<0.05)$ compared to the negative control (ANOVA followed by Newman Keuls).
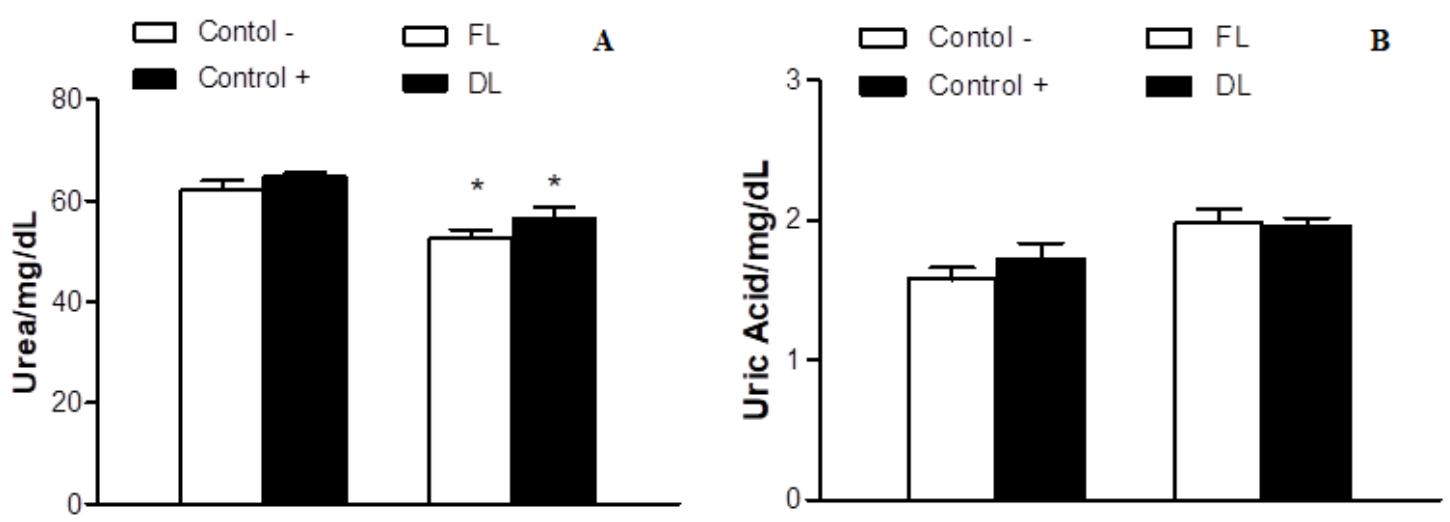

Source: Authors.

Urea nitrogen reduction is found in diseases associated with liver failure and hypoprotein diets (Fox et al., 2006). As the plasma urea level is also affected by kidney function, among other factors such as hydration status, despite undergoing variations due to other factors, this marker still serves as a good predictive index of symptomatic renal failure (Motta, 2009). Thus, these results corroborate histopathological analyses, as well as analyses of AST and ALT, also indicating that the treatments did not affect the renal function of the animals.

\subsubsection{Determination of the total plasma protein (TPP)}

Significantly increased values of TPP compared to the negative control were shown for the group treated with dry leaf (DL) extract (Figure 5). 
TPP is a measure of the combined concentration of albumin and globulins in the plasma (Taylor, Brazil, \& Hillyer, 2010). A gradual increase in the total protein over days/weeks usually reflects an increase in the globulin component as a result of a response to infection and/or inflammation (Taylor et al., 2010). As albumin makes up more than half of the total protein present in plasma, and the only clinical situation that causes an elevation in plasma albumin is dehydration (Walker, Hall, \& Hurst, 1990), TPP levels may increase with conditions that cause an abnormally high production of protein (e.g., inflammatory disorders, and a certain type of cancer, such as multiple myeloma) or dehydration (Hall, 2013; Taylor et al., 2010; Walker et al., 1990).

Figure 5. Evaluation of the effects on the total plasma protein (TPP) after 15 days of clinical trial using negative and positive controls, and extracts of fresh (FL) and dried (DL) leaves of P. carthagenensis, collected in Campo Grande, Mato Grosso do Sul. Data were expressed as mean, and bar graphs, as SEM (standard error of mean) of g/dL of plasma.

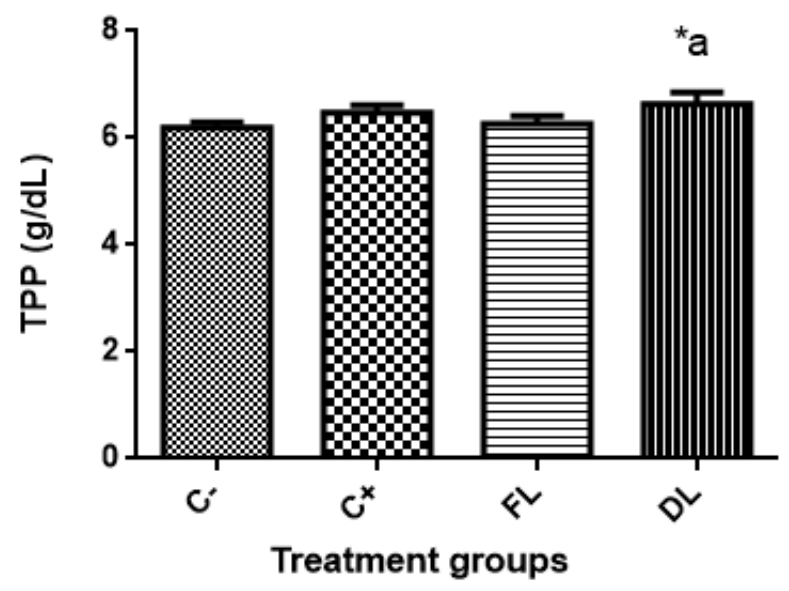

Source: Authors.

Through our results for daily water consumption, white blood cells and urea, we can suggest that dehydration could be responsible for both results, urea and TPP, mainly for the group treated with dried leaves (DL). This was because, although non-significant due to the large standard deviation, the mean water intake by the DL group was lower than that of the other groups.

\subsubsection{Dosage of acetylcholinesterase (AChE)}

Based on the results (Table 4), it can be considered that the assay performed with the extract of the fresh leaves (FL group) showed a lower amount of the enzyme concentration of acetylcholinesterase compared to the negative control, presenting a result similar to the positive control. The group treated with the aqueous extract of the dried leaves (DL) showed a higher enzymatic concentration of AChE, but a lower concentration in relation to the negative control. 
Research, Society and Development, v. 10, n. 4, e22810414059, 2021

(CC BY 4.0) | ISSN 2525-3409 | DOI: http://dx.doi.org/10.33448/rsd-v10i4.14059

Table 4. Results of the enzymatic concentration of acetylcholine in the blood plasma of Wistar rats after 15 days of clinical trial using negative and positive controls, and extracts of fresh (FL) and dried (DL) leaves of $P$. carthagenensis, at $200 \mu \mathrm{g} / \mathrm{Kg}$ animal, collected in Campo Grande, Mato Grosso do Sul.

\begin{tabular}{llllll}
\hline \multicolumn{5}{c}{ AChE enzymatic results } \\
\hline$[$ Enzymes] & Standard & C + & C- & FL & DL \\
$\left.(\mu \mathrm{j} \mathrm{mL})^{-1}\right)$ & 5.649 & 5.767 & 6.900 & 5.572 & 6.096 \\
\hline SEM & 0.133 & 0.084 & 0.198 & 0.114 & 0.064 \\
CV $(\%)$ & 25.27 & 19.67 & 38.18 & 27.25 & 14.03 \\
\hline & $\mathrm{a}$ & $\mathrm{a}$ & $\mathrm{c}$ & $\mathrm{a}$ & $\mathrm{b}$ \\
\hline
\end{tabular}

Data were expressed as mean and SEM (standard error of mean). CV\% $=$ Coefficient of variation; $\mathrm{a}=$ internal reference standard. FL $=$ fresh leaves extract; $\mathrm{DL}=$ dry leaves extract.

Source: Authors.

The cholinergic system is based on the neurotransmitter acetylcholine $(\mathrm{ACh})$, found widely distributed in the central, peripheral, autonomic and enteric nervous system, as well as in the neuromuscular junctions (Amenta \& Tayebati, 2008; Pohanka, 2011; Ventura et al., 2010). Cholinesterases are a family of enzymes that catalyze the hydrolysis of ACh into choline and acetic acid, an essential process allowing for the restoration of the cholinergic neuron (Pohanka, 2011). They are present in presynaptic nerve endings, where ACh is continuously hydrolyzed and resynthesized (Rang, Ritter, Flower, \& G., 2016). AChE (EC 3.1.1.7.) participates in cholinergic neurotransmission by hydrolyzing acetylcholine (Pohanka, 2011; Rang et al., 2016). It is a key enzyme in the nervous system that terminates nerve impulses by catalyzing the hydrolysis of neurotransmitter ACh (Lionetto, Caricato, Calisi, Giordano, \& Schettino, 2013). After its release, ACh diffuses through the synaptic cleft and combines with receptors located in the postsynaptic cell (Rang et al., 2016). AChE inhibitors or anti-cholinesterases inhibit the cholinesterase enzyme from breaking down $\mathrm{ACh}$, increasing both the level and duration of the neurotransmitter's action (Colović, Krstić, Lazarević-Pašti, Bondžić, \& Vasić, 2013). Measurement of AChE inhibition has been increasingly used in the last two decades as a biomarker of neurotoxicity in Environmental and Occupational Medicine (Lionetto et al., 2013). In this context, the results of this study demonstrating that FL aqueous extract of $P$. carthagenensis inhibited AChE suggest that the extract could be used to provide an improvement in patients with Alzheimer's disease (AD), since the only effective current treatment for AD targets the cholinergic system using anti-cholinesterase compounds (Oh, Houghton, Whang, \& Cho, 2004).

\section{Final Considerations}

In conclusion, the extracts of fresh and dried leaves of P. carthagenensis at $200 \mu \mathrm{g} / \mathrm{Kg}$ animal were not toxic. This was especially clear for the FL extract, which acted most in inhibiting the AChE enzyme, suggesting a potential use of $P$. carthagenensis tea as an alternative in the treatment of disorders of the CNS, although more modern techniques are necessary to verify its main phytochemical compounds. Thus, the findings demonstrate the therapeutic potential of the fresh aqueous extract of this plant; however, there is a need to continue the study with other concentrations that have an inhibitory effect on AChE, without causing liver damage.

\section{Acknowledgments}

The authors are grateful to the Veterinary Hospital of Anhanguera-Uniderp University, Campo Grande, MS, Brazil for technical support in the hematological analyses, to Professor Ademir Kleber Morbeck de Oliveira for the identification of the species, to the Coordination for Further Training of Graduate Staff (CAPES), for financial support, and to AnhangueraUniderp University, for the scholarship to G.C.Z.N. 
Research, Society and Development, v. 10, n. 4, e22810414059, 2021

(CC BY 4.0) | ISSN 2525-3409 | DOI: http://dx.doi.org/10.33448/rsd-v10i4.14059

\section{References}

Acharezzi, B., Tangerino, G. C., Sperandio, L. G., Mestriner, A. C. D., \& Malfará, W. R. (2015). Avaliação hepática em ratos wistar expostos ao chá de ayahuasca. Saúde e Pesquisa, Maringá (PR), 8(3), 225-232. doi: 10.177651/1983-1870.2015v8n3p423-430

Almersjö, O., Bengmark, S., Engevik, L., Hafström, L. O., Loughridge, B. P., \& Nilsson, L. A. (1968). Serum enzyme changes after hepatic dearterialization in man. Annals of Surgery, 167(1), 9-17. doi: 10.1097/00000658-196801000-00002

Amenta, F., \& Tayebati, S. K. (2008). Pathways of acetylcholine synthesis, transport and release as targets for treatment of adult-onset cognitive dysfunction. Current Medicinal Chemistry, 15, 488-498. doi: 10.2174/092986708783503203

Aronson, J. K. (2014). 76 - plant poisons and traditional medicines. In J. Farrar, P. J. Hotez, T. Junghanss, G. Kang, D. Lalloo \& N. J. White (Eds.), Manson's tropical infectious diseases. (Twenty-third Edition ed., pp. 1128-1150.e1126). London: W.B. Saunders.

Azwanida, N. N. (2015). A review on the extraction methods use in medicinal plants, principle, strength and limitation. Medicinal \& Aromatic Plants, 4(3), 1000196. doi: 10.4172/2167-0412.1000196

Bertucci, A., Haretche, F., Olivaro, C., \& Vázquez, A. (2008). Prospección química del bosque de galería del río uruguay. Revista Brasileira de Farmacognosia, 18(1), 21-25. doi: 10.1590/S0102-695X2008000100006

Blumberg, N., Cholette, J. M., Pietropaoli, A. P., Phipps, R., Spinelli, S. L., Eaton, M. P., Refaai, M. A. (2018). 0.9\% NaCl (normal saline) - Perhaps not so normal after all? Transfusion and Apheresis Science, 57(1), 127-131. doi: 10.1016/j.transci.2018.02.021

Brecher, G. , \& Cronkite, E.P. (1950). Morphology and enumeration of human blood platelets. Journal of Applied Physiology, 3(6), 365-377. doi: 10.1152/jappl.1950.3.6.365

Brecher, G., Schneiderman, M. , \& Cronkite, E.P. (1953). The reproducibility and constancy of the platelet count. American Journal of Clinical Pathology, 23(1), 15-26. doi: 10.1093/ajcp/23.1.15

Broadhurst, R. B., \& Jones, W. T. (1978). Analysis of condensed tannins using acidified vanillin. Journal of the Science of Food and Agriculture, 29(9), 788794. doi: $10.1002 /$ jsfa. 2740290908

Bruce, R., Todd, J. K., \& Ledune, L. (1958). Serum transaminase: Its clinical use in diagnosis and prognosis. British Medical Journal, 2(5105), 1125-1128. doi: $10.1136 / \mathrm{bmj} .2 .5105 .1125$

Buckholtz, N. S., \& Boggan, W. O. (1977). Monoamine oxidase inhibition in brain and liver produced by $\beta$-carbolines: Structure-activity relationships and substrate specificity. Biochemistry and Pharmacology, 26(21), 1991-1996. doi: 10.1016/0006-2952(77)90007-7

Calixto, N. O., Pinto, M. E. F., Ramalho, S. D., Burger, Marcela C. M., Bobey, A. F., Young, M. C. M. . Pinto, A. C. (2016). The genus Psychotria: Phytochemistry, chemotaxonomy, ethnopharmacology and biological properties. Journal of the Brazilian Chemical Society, 27(8), 1355-1378. doi: $10.5935 / 0103-5053.20160149$

Colović, M. B., Krstić, D. Z., Lazarević-Pašti, T. D., Bondžić, A. M., \& Vasić, V. M. (2013). Acetylcholinesterase inhibitors: Pharmacology and toxicology. Current of Neuropharmacology, 11(3), 315-335. doi: 10.2174/1570159X11311030006

Guia brasileiro de boas práticas para eutanásia em animais: Conceitos e procedimentos recomendados. (2013).

Corrêa, L. R., Soares, G. L. G., \& Fett-Neto, A. G. (2008). Allelopathic potential of Psychotria leiocarpa, a dominant understorey species of subtropical forests. South African Journal of Botany, 74(4), 583-590. doi: 10.1016/j.sajb.2008.02.006

De Smet, Peter A. G. M. (1995). Health risks of herbal remedies. Drug Safety, 13(2), 81-93. doi: 10.2165/00002018-199513020-00003

Dias Souza, R. K., Mendonça, A. C. A. M., \& Silva, M. A. P. (2013). Aspectos etnobotânicos, fitoquímicos e farmacológicos de espécies de rubiaceae no brasil. Revista Cubana de Plantas Medicinales, 18(1), 140-156.

Do, Q. D., Angkawijaya, A. E., Tran-Nguyen, P. L., Huynh, L. H., Soetaredjo, F. E., Ismadji, S., \& Ju, Yi-Hsu. (2014). Effect of extraction solvent on total phenol content, total flavonoid content, and antioxidant activity of Limnophila aromatica. Journal of Food and Drug Analysis, 22(3), 296-302. doi: https://doi.org/10.1016/j.jfda.2013.11.001

dos Santos, R.G. (2013). Safety and side effects of ayahuasca in humans - an overview focusing on developmental toxicology. Journal os Psychoactive Drugs, 45(1), 68-78. doi: 10.1080/02791072.2013.763564

Faria, R. R., \& Araujo, A. C. (2015). Fruit set of distylous Psychotria carthagenensis jacq. (rubiaceae) mediated by Apis mellifera (apidae) and species of Augochloropsis (halictidae). Acta Botanica Brasiliensis, 29(2), 278-281. doi: 10.1590/0102-33062014abb0006

Faria, R. R., Ferrero, V., Navarro, L., \& Araujo, A. C. (2012). Flexible mating system in distylous populations of Psychotria carthagenensis jacq. (rubiaceae) in brazilian cerrado. Plant Systematics and Evolution, 298(3), 619-627. doi: 10.1007/s00606-011-0571-7

Faria, R. R., \& Lima, T. N. (2008). Spiders associated with Psychotria carthagenensis jacquin. (rubiaceae): Vegetative branches versus inflorescences, and the influence of Crematogaster sp. (Hymenoptera, formicidae), in south-pantanal, brazil. Brazilian Journal of Biology, 68(2), 229-232. doi: 0.1590/S151969842008000200002

Fontoura, F. M., Matias, R., Ludwig, J., Oliveira, A. K. M., Bono, J. A. M., Martins, P. F. R. B., Guedes, N. M. R. (2015). Seasonal effects and antifungal activity from bark chemical constituents of Sterculia apetala (malvaceae) at pantanal of miranda, mato grosso do sul, brazil. Acta Amazonica, 45, 283-292. 
Research, Society and Development, v. 10, n. 4, e22810414059, 2021

(CC BY 4.0) | ISSN 2525-3409 | DOI: http://dx.doi.org/10.33448/rsd-v10i4.14059

Formagio, A. S. N., Volobuff, C. R. F., Santiago, M., Cardoso, C. A. L., Vieira, M. C., \& Pereira, Z. V. (2014). Evaluation of antioxidant activity, total flavonoids, tannins and phenolic compounds in Psychotria leaf extracts. Antioxidants, 3(4), 745-757. doi: 10.3390/antiox3040745

Fox, J. G, Barthold, Stephen, D., Muriel, Newcomer, C. E, Quimby, F. W., \& Smith, A. (2006). The mouse in biomedical research: Normative biology, husbandry, and models (2nd ed. Vol. 3). London: Elsevier (Academic Press).

Frecska, E., Bokor, P., \& Winkelman, M. (2016). The therapeutic potentials of ayahuasca: Possible effects against various diseases of civilization. Frontiers in Pharmacology, 7, 35. doi: 10.3389/fphar.2016.00035

Gambelunghe, C., Aroni, K., Rossi, R., Moretti, L., \& Bacci, M. (2008). Identification of n,n-dimethyltryptamine and $\beta$-carbolines in psychotropic ayahuasca beverage. Biomedical Chromatography, 22(10), 1056-1059. doi: 10.1002/bmc.1023

Hall, E. J. (2013). Small intestine. In R. J. Washabau \& M. J. Day (Eds.), Canine and feline gastroenterology (pp. 651-728). Saint Louis: W.B. Saunders.

Harborne, A.B. (Ed). (1998). Phytochemical methods: A guide to modern techniques of plant analysis. Dordrecht: Springer.

Idoh, K., Agbonon, A., Potchoo, Y., \& Gbeassor, M. (2016). Toxicological assessment of the hydroethanolic leaf extract of Clerodendrum capitatum in wistar rats. Pan African Medical Journal, 24, 66. doi: 10.11604/pamj.2016.24.66.8771

Jackson, J. K., \& Derleth, D. P. (2000). Effects of various arterial infusion solutions on red blood cells in the newborn. Archives of Disease in Childhood Fetal and Neonatal Edition, 83(2), F130-F134. doi: 10.1136/fn.83.2.F130

Koch, A. K., Silva, P. C., \& Silva, C. A. (2010). Biologia reprodutiva de Psychotria carthagenensis (rubiaceae), espécie distílica de fragmento florestal de mata ciliar, centro-oeste do brasil. Rodriguésia, 61, 551-558. doi: 10.1590/2175-7860201061314

Leal, M. B., \& Elisabetsky, E. (1996). Absence of alkaloids in Psychotria carthagenensis jacq. (rubiaceae). Journal of Ethnopharmacology, 54(1), 37-40. doi: $10.1016 / 0378-8741(96) 01448-1$

Lionetto, M. G., Caricato, R., Calisi, A., Giordano, M. E., \& Schettino, .T. (2013). Acetylcholinesterase as a biomarker in environmental and occupational medicine: New insights and future perspectives. Biomed Research International, 2013, 321213-321213. doi: 10.1155/2013/321213

Liu, W., Yin, D., Li, N., Hou, X., Wang, D., Li, D., \& Liu, J. (2016). Influence of environmental factors on the active substance production and antioxidant activity in Potentilla fruticosa 1. And its quality assessment. Science Reports, 6(1), 28591. doi: 10.1038/srep28591

Lopes, S. O., Moreno, P. R. H., \& Henriques, A. T. (2000). Growth characteristics and chemical analysis of Psychotria carthagenensis cell suspension cultures. Enzyme and Microbial Technology, 26(2), 259-264. doi: 10.1016/S0141-0229(99)00148-9

Magedans, Y. V. S., Rodrigues-Corrêa, K. C. S., Costa, C. T., Matsuura, H. N., \& Fett-Neto, A. G. (2019). Sustainable production of bioactive alkaloids in Psychotria 1. of southern brazil: Propagation and elicitation strategies. Acta Botica Brasiliensis, 33(4), 607-617. doi: 10.1590/0102-33062019abb0114

Martins, D., \& Nunez, C. V. (2015). Secondary metabolites from rubiaceae species. Molecules, 20(7), 13422-13495. doi: 10.3390/molecules200713422

Matos, F. J. A. (2009). Introdução a fitoquímica experimental. (3 ed.). Fortaleza: Edições UFC.

McKenna, D. J. (2004). Clinical investigations of the therapeutic potential of ayahuasca: Rationale and regulatory challenges. Pharmacol Ther, 102(2), 111129. doi: 10.1016/j.pharmthera.2004.03.002

McKenna, D. J., Towers, G. H. N., \& Abbott, F. (1984). Monoamine oxidase inhibitors in south american hallucinogenic plants: Tryptamine and $\beta$-carboline constituents of ayahuasca. Journal of Ethnopharmacology, 10(2), 195-223. doi: 10.1016/0378-8741(84)90003-5

Melo, S. K. Mendes, L., Batista, L., Almeida, T. L. A. Craveiro, R., Willcox, E., Manso, H. E. C. C. C. , \& Manso Filho, H. C. (2013). Índices hematimétricos e bioquímica sanguínea no cavalo de cavalgada em condições tropicais. Ciência Animal Brasileira, 14(2), 208-215.

Morado, C. M., Araújo, F. G., \& Gomes, I. D. (2017). The use of biomarkers for assessing effects of pollutant stress on fish species from a tropical river in southeastern brazil. Acta Scientiarum Biological Science, 39(4), 431-439. doi: 10.4025/actascibiolsci.v39i4.34293

Moraes, T. M., de Araújo, M. H., Bernardes, N. R., de Oliveira, D. B., Lasunskaia, E. B., Muzitano, M. F., \& Da Cunha, M. (2011). Antimycobacterial activity and alkaloid prospection of Psychotria species (rubiaceae) from the brazilian atlantic rainforest. Planta Medica, 77(9), 964-970. doi: 10.1055/s-0030-1250656

Morais, J. A. (2014). Toxicidade aguda e crônica do chá ayahuasca (banisteriopsis caapi e psychotria viridis), por análise histológica em ratas wistar. (Mestrado Dissertação), Universidade de Brasília, Brasília/Brasil.

Moreira, C. N., Souza, S. N., Barini, A. C., Araújo, E. G., \& Fioravanti, M. C. S. (2012). Serum $\gamma$-glutamyltransferase activity as an indicator of chronic liver injury in cattle with no clinical signs. Arquivo Brasileiro de Medicina Veterinária e Zootecnia, 64(6), 1403-1410. doi: 10.1590/S0102-09352012000600001

Motta, V. T. (2009). Bioquímica clínica para o laboratório: Princípios e interpretações. (5 a ed.). Curitiba: Medbook.

Narra, M. R. (2016). Single and cartel effect of pesticides on biochemical and haematological status of Clarias batrachus: A long-term monitoring. Chemosphere, 144, 966-974. doi: 10.1016/j.chemosphere.2015.09.065

Oh, M. H., Houghton, P. J., Whang, W. K., \& Cho, J. H. (2004). Screening of korean herbal medicines used to improve cognitive function for anticholinesterase activity. Phytomedicine, 11(6), 544-548. doi: 10.1016/j.phymed.2004.03.001 
Research, Society and Development, v. 10, n. 4, e22810414059, 2021

(CC BY 4.0) | ISSN 2525-3409 | DOI: http://dx.doi.org/10.33448/rsd-v10i4.14059

Oliveira, R. A. G., Takadachi, M. M., Nonoyama, K., \& Barretto, O. C. O. (2003). The absolute recommendation of chamber neubauer method for platelets counting instead of indirect methods in severe thrombocytopenic patients. Jornal Brasileiro de Patologia e Medicina Laboratorial, 39(2), 139-141. doi: $10.1590 /$ S1676-24442003000200008

Pohanka, M. (2011). Cholinesterases, a target of pharmacology and toxicology. Biomedical Paper of the Medical Faculty of the University Palacky Olomouc Czech Repub, 155(3), 219-230. doi: 10.5507/bp.2011.036

Porto, D., Henriques, A., \& Fett-Neto, A. (2009). Bioactive alkaloids from south american Psychotria and related species. The Open Bioactive Compounds Journal, 2, 29-36. doi: 10.2174/1874847300902010029

Ramaiah, SK. (2007). A toxicologist guide to the diagnostic interpretation of hepatic biochemical parameters. Food Chemistry and Toxicology, 45(9), 15511557.

Rang, H. P., Ritter, J. M., Flower, R. J., \& G., Henderson. (2016). Rang \& dale's pharmacology. (8th Edition ed.). London: Churchill Livingstone Elsevier.

Reflora. (2020). Psychotria in flora do brasil 2020 em construção: Psychotria carthagenensis jacq. Retrieved 03 Fev. 2020, from http://reflora.jbrj.gov.br/reflora/listaBrasil/FichaPublicaTaxonUC/FichaPublicaTaxonUC.do?id=FB14167

Rivier, L., \& Lindgren, Jan-Erik. (1972). "Ayahuasca," the south american hallucinogenic drink: An ethnobotanical and chemical investigation. [journal article]. Economic Botany, 26(2), 101-129. doi: 10.1007/bf02860772

Santos, A., \& Mostardeiro, C. (2013). Padronização de metodologia analítica para avaliação da colinesterase plasmática. Revista Contexto \& Saúde, 8(14-15), 23-30. doi: 10.21527/2176-7114.2008.14/15.23-30

Sanz-Biset, J., Campos-de-la-Cruz, J., Epiquién-Rivera, M. A., \& Cañigueral, S. (2009). A first survey on the medicinal plants of the chazuta valley (Peruvian amazon). Journal of Ethnopharmacology, 122(2), 333-362. doi: 10.1016/j.jep.2008.12.009

Sharma, T., \& Kanwar, S. (2018). Phytomolecules for obesity and body weight management. Journal of Biochemistry \& Cell Biology, 1(1), 101.

Shukla, S., \& Singh, S. (2001). Alkaloid profile in relation to different developmental stages of Papaver somniferum 1. Phyton - Annales Rei Botanicae, 41, 8796.

Silva, T. D. P., Lacerda, L. A., Carvalho, L. S., Souza, S. N., Arnhold, E., Sant'Ana, F. J. F., \& Fioravanti, M. C. S. (2017). Manual and automated blood cells count in ocelots (Leopardus pardalis - Linnaeus, 1758). Arquivo Brasileiro de Medicina Veterinária e Zootecnia, 69(5), 1191-1197. doi: 10.1590/1678-41629299

Simão, A. Y., Gonçalves, J., Duarte, A. P., Barroso, M., Cristóvão, A. C., \& Gallardo, E. (2019). Toxicological aspects and determination of the main components of ayahuasca: A critical review. Medicines (Basel), 6(4), pii: E106. doi: 10.3390/medicines6040106

Simpson, D., \& Amos, S. (2017). Chapter 12 - other plant metabolites. In S. Badal \& R. Delgoda (Eds.), Pharmacognosy (pp. 267-280). Boston: Academic Press.

Sousa, C. M. M., Silva, H. R., Vieira-Jr., G. M., Ayres, M. C. C., Costa, C. L. S. , Araújo, D. S., Chaves, M.H. (2007). Fenóis totais e atividade antioxidante de cinco plantas medicinais. Química Nova, 30, 351-355.

Souza, F. A., Sena, J., Maranho, L. T., Oliveira, C. M. R., \& Guimarães, A. T. B. . (2008). Caracterização fitoquímica preliminar de infusões populares obtidas das partes aéreas das espécies Apium leptophylum (pers.) f. Muell. Ex benth. (apiaceae), Elvira biflora 1. (dc.) e Vernonia polyanthes less. (asteraceae). Revista Brasileira de Farmacognosia, 89(1), 24-27.

Sreevidya, N., \& Mehrotra, S. (2003). Spectrophotometric method for estimation of alkaloids precipitable with dragendorff's reagent in plant materials. Journal of AOAC International, 86(6), 1124-1127. doi: 10.1093/jaoac/86.6.1124

Taylor, F. G. R., Brazil, T. J., \& Hillyer, M. H. (2010). Diagnostic techniques in equine medicine. (Second Edition ed.). Edinburgh: W.B. Saunders.

Ventura, A. L. M. , Abreu, P. A., Freitas, .R. C. C., Sathler, P. C., Loureiro, N., \& Castro, H. C. (2010). Sistema colinérgico: Revisitando receptores, regulação e a relação com a doença de alzheimer, esquizofrenia, epilepsia e tabagismo. Revista de Psiquiatria Clínica, 37(2), 66-72. doi: 10.1590/S010160832010000200007

Vitarelli, N. C., \& Santos, M. (2009). Anatomia de estípulas e coléteres de Psychotria carthagenensis jacq. (rubiaceae). Acta Botanica Brasiliensis, 23(4), 923928. doi: 10.1590/S0102-33062009000400002

Walker, H. K., Hall, W. D., \& Hurst, J. W. (1990). Clinical methods: The history, physical, and laboratory examinations. (3rd edition ed.). Boston: Butterworths.

Yang, H., Zhang, H., Yang, C., \& Chen, Y. (2016). Chemical constituents of plants from the genus psychotria. Chemistry and Biodiversity, 13(7), 807-820. doi: $10.1002 / \mathrm{cbdv} .201500259$

Yang, L., Wen, Kui-Shan, Ruan, X., Zhao, Ying-Xian, Wei, F., \& Wang, Q. (2018). Response of plant secondary metabolites to environmental factors. Molecules, 23(4), 762. doi: 10.3390/molecules23040762

Zhang, Cui-Xian, Zhang, Dong-Mei, Chen, M., Guan, Shan-Yue, Yao, Jun-Hua, H., Xi-Xin, Ye, Wen-Cai. (2013). Antiproliferative triterpenoid saponins from the stem of psychotria sp. Planta Medica, 79, 978-986. doi: 10.1055/s-0032-1328650 